\title{
Can lactoferrin modulate the immunostimulant activity of levamisole in rats immunosuppressed by cyclophosphamide?
}

\author{
Laktoferrin siklofosfamid ile immunsuprese ratlarda levamizol'un immün stimulan etkisini \\ düzenleyebilir mi?
}

Wafaa Abdou Mohamed Mohamed

\begin{abstract}
Objective: The aim of this study was to study the immunomodulatory activity improvement of levamisole by using lactoferrin when applied to immunosuppressed rat model.

Methods: The study was designed as follows, 140 male albino rats $(250-280 \mathrm{~g}) 14$ weeks old were used in our work. Rats were randomly divided into seven groups, 20 in each. The group I was kept as a control, group II was given cyclophosphamide (CYP) at a single intraperitoneal dose of (250 mg/kg body weight), group III CYP and lactoferrin (Lac) treated group, group IV orally administrated Lac only $(0.5 \%)$ in drinking water, group $V$ treated with CYP and levamisole, group VI administrated levamisole orally at a dose of ( $2.5 \mathrm{mg} / \mathrm{kg}$ body weight) and group VII was given CYP, Lac and levamisole. Animals were sacrificed and two separate blood samples were collected after 21 days from the beginning of the experiment for measuring the total and differential leukocyte count, serum total proteins, albumin, alpha globulin, beta globulin and gamma globulin, Nitric oxide (NO) production and lysozyme activity.
\end{abstract}

Results: CYP group showed significant decrease in the above mentioned parameters, which were improved after administration of both lactoferrin and levamisole.

Conclusion: Our study concluded that lactoferrin improve the immunostimulant effect of levamisole in CYP. immunosuppressed rats. J Clin Exp Invest 2014; 5 (1): 48-53

Key words: Bovine lactoferrin (Lac), Levamisole , Cyclophosphamide(CYP), Immunomodulation, Lysozyme assay

\section{INTRODUCTION}

Immunostimulants are agents that trigger the nonspecific immune response and result in enhanced disease resistance. Several compounds have been reported to have immunostimulation properties.

\section{ÖZET}

Amaç: Bu çalışmanın amacı immunsuprese rat modelinde laktoferrin kullanılarak levamizolün immün düzenleyici aktivitesini araştırmaktır.

Yöntemler: Çalışma planı: Çalışmada 14 haftalık 140 erkek albino rat $(250-280 \mathrm{~g})$ kullanıldı. Ratlar herbirinde 20 rat bulunan 7 gruba ayrıldı. Birinci grup Kontrol grubu, Grup II'ye siklofosfamid tek intraperitoneal dozda (250 $\mathrm{mg}$ ), Grup III siklofosfamid ve laktoferrin verilen grup, Grup IV oral içme suyu içinde sadece Laktoferrin $(\% 0,5)$ verilen grup; Grup V siklofosfamid ve levamizol ile tedavi edildi, Grup Vl'ya oral levamizol $(2,5 \mathrm{mg} / \mathrm{kg})$ verildi ve GrupVII'ye laktoferrin, siklofosfamid ve lavamizol verildi. Hayvanlar feda edildi ve çalışmanın başlamasını takib eden 21. Günde iki farklı kan örneği alındı ve total ve ayırıcı lökosit sayısı, serum total proteinleri, albümin, alfa globülin, beta globülin, gama globülin, nitrik oksit üretimi ve lizozim aktivitesi ölçüldü.

Bulgular: Siklofosfamid grubunun yukarıda bahsedilen parametrelerinde anlamlı düşüş gözlendi ki bu durum hem laktoferrin hem de levamizol verilmesi ile düzeldi.

Sonuç: Bu çalışmamızda siklofosfamid ile immunsuprese edilen ratlarda laktoferrinin levamizolün immunstimulan etkisini iyileştirdiği sonucuna varıldı.

Anahtar kelimeler: Sığır laktoferrini, Levamizol, Siklofosfamid, Immunmodülasyon, Lizozim deneyi

Many of these are derivatives or cellular components of bacterial, fungal or animal origin such as laminarin, barley, glucan, lactoferrin, levamisole, lipopolysaccharides, curdlan, scleroglucan, zymosan, inulin, chitosan, glucans, dextran, lentinan, saponins, herbal extracts, peptidoglycans [1].

Department of Clinical Pathology, Faculty of Veterinary Medicine, Zagazig University, 44511 Zagazig, Egypt

Correspondence: Wafaa Abdou Mohamed Mohamed,

Dept. Clinical Pathology, Faculty of Veterinary, Zagazig University, 44511 Zagazig, Egypt. Email: waffa.clinical@yahoo.com Received: 20.12.2013, Accepted: 27.02.2014

Copyright @ JCEI / Journal of Clinical and Experimental Investigations 2014, All rights reserved 
Cyclophosphamide (CYP) is an alkylating agent widely used as cancer chemotherapy and autoimmune disease therapy [2]. CYP is a well-known and powerful immunosuppressive agent with dosespecific effects. Low dose of CYP acts mainly on $B$ cell regions in lymphoid organs, but high doses have an effect upon both $B$ and $T$ cell regions [3].Levamisole is mainly used as an anthelmintic agent in veterinary purpose [4] but in some countries, its use is limited to immunomodulatory agent in humans in some cancers. It is having an immunostimulating effect in immunosuppressed condition [5] but it has been found that it is also having a useful effect in autoimmune diseases like nephrotic syndrome and rheumatoid arthritis. It helps to make steroid free period of up to 6 months to 1 year in nephrotic syndrome [6,7].

Lactoferrin (Lac) is an $80 \mathrm{kDa}$ multifunctional glycoprotein belonging to the transferrin family. Lac is primarily present in milk, and is also found in other biological fluids, such as saliva, tears, bile and pancreatic juice [8]. It has been widely documented that Lac displays antimicrobial activity against many different pathogenic agents. This activity was attributed to its ability, to bind iron with a high affinity and unlike transferrin, retain its bound iron under acidic conditions. Lac is considered to be a part of the innate immune system and takes part in specific immune reactions, but in an indirect way [9].Lac has a wide range of effects on the immune system, both in vivo and in vitro [10]. Lactoferrin is a cell-secreted mediator that bridges innate and adaptive immune function in mammals. It is a pleiotropic molecule that directly assists in the influence of presenting cells for the development of T-helper cell polarization [11].

The objective of the present research work is to check the effect of to study the improvement of the levamisole immunomodulation action when given with lactoferrin.

\section{METHODS}

\section{Animals}

140 male albino rats (250-280 g) 14 weeks old were obtained from the faculty of Veterinary Medicine, Zagazig University to use for the study. The rats were distributed in seven groups, housed in solidbottomed cages containing bedding of wood shavings and were allowed food and water ad libitum. The room temperature was maintained at $21-24^{\circ} \mathrm{C}$, and a $12 \mathrm{~h}$ light/dark cycle was employed. All animals were acclimatized for 1 week before starting the experiment. The ethical standards guidelines for the care and use of laboratory animals provided by the animal ethics committee (institutional or national) and with the Committee for the Purpose of Control and Supervision of Experiments on Animals (CPCSEA) were used.

\section{Chemicals}

Immunostimulant agent (levamisole 10\%) levamisole hydrochloride (pharma sewede,Egypt).Bovine lactoferrin was purchased from Sigma-Aldrich Chemie $\mathrm{GmbH}$. Endoxan ${ }^{\circledR}$ injection vial of Endoxan 1 g contains: $1.069 \mathrm{~g}$ cyclophosphamide monohydrate (equivalent to $1 \mathrm{~g}$ anhydrous cycphosphamide) as the active ingredient was manufactured by industrias Farmaceuticas Almirall Prodesfarma S.L.C/San Juan no.9,08560 Manlleu/Spain for Baxter Oncology Gmbh Kantstrasse 2 D-33790 Halle, Germany. All the other chemicals were purchased from standard local sources. All other reagents used were of analytical grade.

\section{Experimental design}

Rats were randomly divided into seven groups; each is consisting of twenty rats. The groups treated as follows. The group I was kept as control, group II was given CYP at a single intraperitoneal dose of $(200 \mathrm{mg} / \mathrm{kg}$ body weight) on the first day of the experiment according to [12], group III was administered CYP and Lac, group IV orally administrated Lac only $(0.5 \%)$ in drinking water during the 21 days of the experiment according to [13], Group V treated with CYP and levamisole. Group VI orally administrated levamisole at a dose of $(2.5 \mathrm{mg} / \mathrm{kg}$ body weight) according to [14]. Group VII was treated with CYP, Lac and levamisole.

\section{Sampling}

Animals were anesthetized with diethyl ether then were scarified at the end of the experiment, two separate blood samples were collected from each of five rats from each group; the 1st sample was taken in EDTA tubes for measurement of total and differential leukocytes count according to $[15,16] .2^{\text {nd }}$ sample was taken without anticoagulant and kept 30 minutes at room temperature then centrifuged at $3000 \mathrm{rpm}$ for 10 minutes and the clear serum was separated carefully and storage at $-20^{\circ} \mathrm{C}$ for the measurement of some immunological parameters.

\section{Evaluation of some immunological parameters}

Serum total protein level was determined according to Henry et al [17], the serum albumin level was determined by the method of Doumas et al [18] 
using the kits provided by Diamond Diagnostics. Regarding to immunological studies, Immunoelectrophoresis of serum proteins has been done using cellulose acetate according to Henry et al [17] , lysozyme activity in blood plasma was determined by the turbidimetric method of [19] modified by [20] and nitric oxide production assay was performed as mentioned by [21].

\section{Lysozyme activity}

Whole blood samples were centrifuged for $5 \mathrm{~min}$ at $1000 \mathrm{~g}$ to separate blood cells from the serum. The serum was diluted 1: 1 with phosphate buffer, and $0.1 \mathrm{ml}$ of the solution was placed in the wells of microplates. $0.5 \mathrm{ml}$ of Micrococcus lysodeikticus bacterial suspension (25 mg bacteria/100 ml phosphate buffer) (Sigma Chemical Co.) was added. Absorbance was measured directly after the addition of bacteria (E0) and after 1, 2, 3 and 30 min (final E). The final absorbance was subtracted from the initial absorbance (E0) to determine lysozyme activity with the use of a standard curve. The standard curve was plotted based on the optical density values for known lysozyme concentrations.

\section{Nitric oxide assay}

NO production was assessed by measuring nitrite accumulation in $72 \mathrm{~h}$ culture supernatants using the Griess reaction. Briefly, $100 \mu$ l of $0.5 \%$ sulfanilamide $0.05 \% \mathrm{~N}$-naphtyl-ethylenediamine hydrochloride in $2.5 \% \mathrm{H}_{3} \mathrm{PO}_{4}$ (Griess reagent) [22] were added to $100 \mu \mathrm{l}$ of supernatants and incubated for $5 \mathrm{~min}$ at room temperature in the dark. The absorbance was then measured at $550 \mathrm{~nm}$ and nitrite concentrations were extrapolated from a sodium nitrite standard curve.

\section{Statistical analysis}

The GRAPHPAD (ISI Software, Philadelphia, PA, USA) computer program was used to conduct regression analysis and to plot collected data. Data were expressed as means \pm standard error (SE). Assessment of the results was performed using one-way analysis of variance (ANOVA) procedure followed by Duncan's Multiple Range test. The 0.05 level of probability was used as the criterion for significance [23].

\section{RESULTS}

\section{Leukogram changes}

In the present work, regarding to the result of leukogram, the total leukocytes, neutrophil, lymphocyte and monocyte were significantly decreased in CYP - immunosuppressed group when compared with the control group. In CYP- immunosuppressed animals treated with Lac in GP. (3), levamisole in GP. (6) and both Lac and levamisole in GP. (7), these parameters were improved when compared with CYP treated groups. The highest improvement was found in the CYP -immunosuppressed rats treated with lactoferrin and levamisole together. In lactoferrin, levamisole treated groups, the leukogram showed nosignificant change in comparison with control group (Table1).

Table 1. Changes on leukogram (TLC, neutrophils, lymphocyte, eosinophil, basophil and monocyte) in all experimental groups

\begin{tabular}{lcccccc}
\hline Group & $\begin{array}{c}\text { TLC } \\
\times 10^{3} / \mu \mathrm{l}\end{array}$ & $\begin{array}{c}\text { Neutrophils } \\
\mathrm{x} 10^{3} / \mu \mathrm{l}\end{array}$ & $\begin{array}{c}\text { Lymphocyte } \\
\times 10^{3} / \mu \mathrm{l}\end{array}$ & $\begin{array}{c}\text { Eosinophil } \\
\times 10^{3} / \mu \mathrm{l}\end{array}$ & $\begin{array}{c}\text { Basophil } \\
\times 10^{3} / \mu \mathrm{l}\end{array}$ & $\begin{array}{c}\text { Monocyte } \\
\times 10^{3} / \mu \mathrm{l}\end{array}$ \\
\hline Group I & $8.51^{\mathrm{a}} \pm 0.21$ & $2.90^{\mathrm{a}} \pm 0.34$ & $4.30^{\mathrm{a}} \pm 0.12$ & $0.81 \pm 0.34$ & $0.06^{\mathrm{a}} \pm 0.01$ & $0.42^{\mathrm{ab}} \pm 0.04$ \\
Group II & $4.45^{\mathrm{d}} \pm 0.06$ & $1.58^{\mathrm{b}} \pm 0.08$ & $2.05^{\mathrm{e}} \pm 0.05$ & $0.70 \pm 0.09$ & $0.00^{\mathrm{b}} \pm 0.00$ & $0.11^{\mathrm{d}} \pm 0.02$ \\
Group III & $6.28^{\mathrm{bc}} \pm 0.16$ & $1.95^{\mathrm{b}} \pm 0.06$ & $3.23^{\mathrm{cd}} \pm 0.14$ & $0.78 \pm 0.09$ & $0.02^{\mathrm{b}} \pm 0.00$ & $0.29^{\mathrm{bc}} \pm 0.04$ \\
Group IV & $9.17^{\mathrm{a}} \pm 0.14$ & $3.15^{\mathrm{a}} \pm 0.33$ & $4.56^{\mathrm{a}} \pm 0.09$ & $0.89 \pm 0.26$ & $0.06^{\mathrm{a}} \pm 0.01$ & $0.50^{\mathrm{a}} \pm 0.06$ \\
Group V & $5.61^{\mathrm{c}} \pm 0.48$ & $1.69^{\mathrm{b}} \pm 0.18$ & $2.98^{\mathrm{d}} \pm 0.25$ & $0.69 \pm 0.10$ & $0.01^{\mathrm{b}} \pm 0.01$ & $0.21^{\mathrm{cd}} \pm 0.06$ \\
Group VI & $8.52^{\mathrm{a}} \pm 0.45$ & $2.95^{\mathrm{a}} \pm 0.34$ & $4.14^{\mathrm{ab}} \pm 0.08$ & $0.84 \pm 0.38$ & $0.06^{\mathrm{a}} \pm 0.01$ & $0.40^{\mathrm{ab}} \pm 0.05$ \\
Group VII & $6.44^{\mathrm{b}} \pm 0.38$ & $2.11^{\mathrm{b}} \pm 0.04$ & $3.70^{\mathrm{bc}} \pm 0.37$ & $0.81 \pm 0.06$ & $0.02^{\mathrm{b}} \pm 0.00$ & $0.29^{\mathrm{bc}} \pm 0.04$ \\
\hline p value & $<0.001$ & $\mathbf{0 . 0 0 1}$ & $<0.001$ & $\mathbf{0 . 9 9 5}$ & $\mathbf{0 . 0 0 2}$ & $<0.001$ \\
\hline
\end{tabular}

\section{Immunological parameter changes}

As shown in Tables $(2,3)$, significant decrease in serum total proteins, albumin, $\alpha$-globulin, $\beta$-globulin and $\mathrm{Y}$-globulin levels, Nitric oxide (NO) production and lysozyme activity was found in CYP -immunosuppressed group when compared with the control 
group . In CYP- immunosuppressed animals treated with Lac in GP. (3), levamisole in GP. (6) and both Lac and levamisole in GP. (7), these parameters were improved when compared with CYP-immunosuppressed groups. The highest improvement was found in the CYP- immunosuppressed rats treated with lactoferrin and levamisole together. In lactoferrin, levamisole treated groups, the above mentioned parameters showed no significant change in comparison with the control group.
Table 2. Changes on serum total proteins, albumin, a-globulin, $\beta$-globulin and $\mathrm{Y}$-globulin in all experimental groups

\begin{tabular}{lccccc}
\hline Group & $\begin{array}{c}\text { T. Protein } \\
\text { g/dl }\end{array}$ & $\begin{array}{c}\text { Albumin } \\
\text { g/dl }\end{array}$ & $\begin{array}{c}\text { a-globulin } \\
\text { g/dl }\end{array}$ & $\begin{array}{c}\text { B-globulin } \\
\text { g/dl }\end{array}$ & $\begin{array}{c}\text { Y-globulin } \\
\text { g/dl }\end{array}$ \\
\hline Group I & $8.89^{\mathrm{a}} \pm 0.06$ & $4.03^{\mathrm{a}} \pm 0.05$ & $1.58^{\mathrm{a}} \pm 0.12$ & $1.41^{\mathrm{a}} \pm 0.13$ & $1.87^{\mathrm{a}} \pm 0.06$ \\
Group II & $4.16^{\mathrm{d}} \pm 0.38$ & $1.81^{\mathrm{d}} \pm 0.11$ & $0.97^{\mathrm{d}} \pm 0.04$ & $0.87^{\mathrm{c}} \pm 0.04$ & $0.51^{\mathrm{d}} \pm 0.03$ \\
Group III & $5.87^{\mathrm{c}} \pm 0.40$ & $2.61^{\mathrm{c}} \pm 0.31$ & $1.17^{\mathrm{cd}} \pm 0.09$ & $1.17^{\mathrm{ab}} \pm 0.06$ & $0.92^{\mathrm{cd}} \pm 0.03$ \\
Group IV & $8.20^{\mathrm{a}} \pm 0.93$ & $3.22^{\mathrm{b}} \pm 0.13$ & $1.51^{\mathrm{a}} \pm 0.04$ & $1.37^{\mathrm{a}} \pm 0.03$ & $2.10^{\mathrm{a}} \pm 0.35$ \\
Group V & $5.54^{\mathrm{cd}} \pm 0.18$ & $2.56^{\mathrm{c}} \pm 0.15$ & $1.16^{\mathrm{cd}} \pm 0.02$ & $1.05^{\mathrm{bc}} \pm 0.05$ & $0.77^{\mathrm{d}} \pm 0.03$ \\
Group VI & $7.60^{\mathrm{ab}} \pm 0.64$ & $3.06^{\mathrm{bc}} \pm 0.12$ & $1.49^{\mathrm{ab}} \pm 0.06$ & $1.28^{\mathrm{ab}} \pm 0.16$ & $1.77^{\mathrm{ab}} \pm 0.03$ \\
Group VII & $6.54^{\mathrm{bc}} \pm 0.18$ & $2.68^{\mathrm{c}} \pm 0.07$ & $1.30^{\mathrm{bc}} \pm 0.07$ & $1.23^{\mathrm{ab}} \pm 0.05$ & $1.33^{\mathrm{bc}} \pm 0.13$ \\
\hline p value & $<0.001$ & $<0.001$ & $<0.001$ & $\mathbf{0 . 0 0 4}$ & $<0.001$ \\
\hline
\end{tabular}

Table 3. Changes on Nitric oxide (NO) production and lysozyme activity in all experimental groups

\begin{tabular}{lcccc}
\hline Group & $\begin{array}{c}\mathrm{NO} \\
\mu \mathrm{g} / \mathrm{ml}\end{array}$ & p value & $\begin{array}{c}\text { ysozyme } \\
\mathrm{mg} / \mathrm{l}\end{array}$ & p value \\
\hline Group I & $0.17^{\mathrm{a}} \pm 0.02$ & $8.63^{\mathrm{a}} \pm 0.21$ & \\
Group II & $0.08^{\mathrm{b}} \pm 0.01$ & $3.8^{\mathrm{c}} \pm 0.18$ & \\
Group III & $0.14^{\mathrm{ab}} \pm 0.03$ & & $5.43^{\mathrm{bc}} \pm 0.32$ & \\
Group IV & $0.18^{\mathrm{a}} \pm 0.02$ & $\mathbf{0 . 0 8 6}$ & $7.96^{\mathrm{a}} \pm 0.99$ & $\mathbf{0 . 0 0 2}$ \\
Group V & $0.14^{\mathrm{ab}} \pm 0.02$ & & $5.46^{\mathrm{bc}} \pm 0.88$ & \\
Group VI & $0.17^{\mathrm{a}} \pm 0.02$ & & $7.96^{\mathrm{a}} \pm 1.08$ & \\
Group VII & $0.16^{\mathrm{a}} \pm 0.03$ & & $7.43^{\mathrm{ab}} \pm 0.37$ & \\
\hline
\end{tabular}

\section{DISCUSSION}

Alkylating agents such as cyclophosphamide (CYP) were developed and introduced into clinical medicine in the 1950s. They were primarily designed as anti-cancer drugs [24]. History has shown that CYP is one of the most potent immunosuppressive drugs. In the present study, we found that CYP induced leukopenia, neutropenia and lymphocytopenia in rats, these results parallel to the result of [25] who demonstrated that CYP is an effective inhibitor of cell mediated immune response and leads to a depletion of lymphocytes in the peripheral blood and tissue. Lactoferrin causes an improvement in leukogram in rats with CYP immunosuppression, we agreed with [26] who said that mice treated with CYP/Lac have a higher content of functional phagocytes (neutrophils and eosinophils) and absolute cell numbers in circulation. Levamisole is an anthel- mintic agent that also apparently enhances immune responsiveness. It is believed that levamisole mediates the immune function of T-cells and stimulates phagocytosis by monocytes [27]. Its immunostimulating effects are greater in immune-compromised animals [28]. According to [29], levamisole is a useful immunostimulatory agent in cancer patients and other patients with impaired cellular immune responses. levamisole in our results, showed improvement of leukogram in immunosuppressed rats , we agreed with the study of [30] which focused on levamisole, and found that the lymphocyte and monocyte percentage were increased on days 7-14 after drug administration and the results of [31] which showed a significant increase in neutrophil and monocyte levels in levamisole treated animals .In addition to these findings, we found that lactoferrin modulate and improved the immunostimulatory effect of levamisole. 
Cyclophosphamide exerts a direct impact on plasma cells, and it inhibits protein synthesis. As shown in Table 2, CYP group showed significant decrease of total protein, albumin, a-globulin, $\beta$-globulin compared with the control group. This result may be due to decrease protein synthesis as a result of liver damage caused by cyclophosphamide as mentioned by [32] who found that hypoproteinemia was observed in rats administered CYP $(150 \mathrm{mg} / \mathrm{kg}$ ) for two days. Also, we found that the CYP-immunosuppressed rats showed significant decrease in $\mathrm{y}$-globulins levels, these findings are parallel to the results observed by [13]. This may be due to the toxic effects of various chemotherapeutic on the liver, including cyclophosphamide, which was found to inhibit selected hepatic enzymes as described by [33]. CYP exerts a specific and not directly toxic effect on the cytochrome P450 system, which converts cyclophosphamide to active metabolites. As the process intensifies (following the administration of higher doses of the drug), hepatocyte dysfunction is observed, including disturbances in the synthesis of selected proteins. A decrease in the levels of $y$-globulins, may be indirectly caused by the inhibition of B cell proliferation by cyclophosphamide [33]. In our study, cyclophosphamide decrease the activity of lysozyme(which is also a Y-globulin), produced by phagocytes and NO production .We agreed with Zhao et al [34] who reported a decrease in serum lysozyme levels in rats administered CYP and the study of [35] that revealed lower levels of nitrogen oxide (NO) following the administration of cyclophosphamide. The immunomodulatory effects of Lactoferrin include influences of the production and release of cytokines such as tumor necrosis factor- $\alpha$ [36], IL-1 $\beta$ [37], IL-8 [38] and nitric oxide [39]. We found that lactoferrin and levamisole elevate the levels of total protein and gamma globins levels when compared with CYP group, this agreed with the result of [13] who found that lactoferrin increased the level of total protein and $\mathrm{y}$-globulin and the result of [31] who said that Levamisole also significantly increased the total protein (7-14 days) and gamma globins levels.

In conclusion, we have demonstrated for the first time that lactoferrin have a synergistic effect to modulate and increase the immunostimulatory effect of levamisole in cyclophosphamide induced immunosuppression in rats.

\section{Competing interests}

The author declares that they have no competing interests.

\section{REFERENCES}

1. Rajasekar T, Usharani J, Sakthivel M, Deivasigamani B. Immunostimulatory effects of Cardiospermum halicacubum against Vibrio parahaemolyticus on tiger shrimp Penaeus monodon. J Chem Pharm Res 2011;3:501-513.

2. Mirkes P E. Cyclophosphamide teratogenesis: a review. Terat Carcin Mutagen 1985;5:75-88.

3. McCormick S, Dowler K, Armstrong J A and Hsiung G D.Cyclophosphamide immunosuppression during lymphotropic herpes-virus infection in the guinea pig model: A histopathologic and virologic study. Am J Pathol 1987;127:538-548.

4. Jabbar A, Zafar I, Dominique K, et al. Anthelmintic resistance: The state of play revisited. Life Sci 2006;79:2413-2431.

5. Farghali $\mathrm{H}$, Masek K. Immunopharmacologic agents in the amelioration of hepatic injuries. Int $\mathrm{J}$ immunopharmacol 1998;20: 125-139.

6. Boyer O, Moulder J K, Grandin L, Somers MJG. Short and long-term efficacy of levamisole as adjunctive therapy in childhood nephrotic syndrome. Pediatr Nephrol 2008;23:575-580.

7. Donia AF, Amer GM, Ahmed HA, et al. Levamisole: adjunctive therapy in steroid dependent minimal change nephrotic children. Pediatr Nephrol 2002;17:355-358.

8. Legrand D, Pierce A, Elass E, Carpentier M, Mariller C, Mazurier J. Lactoferrin structure and functions. Adv Exp Med Biol 2008; 606:163-194.

9. Legrand D, Elass E, Carpentier M, Mazurier J. Lactoferrin: a modulator of immune and inflammatory responses. Cell Mol Life Sci 2005; 62:2549-2559.

10. Brock J H. The physiology of lactoferrin. Biochem Cell Biol 2002;80:1-6.

11. Actor JK, Hwang SA, Kruzel ML. Lactoferrin as a natural immune modulator. Curr Pharm Des 2009;15:19561973.

12. Viswanatha Swamy AHM, Patel UM, Koti C, et al. Cardioprotective effect of Saraca indica against cyclophosphamide induced cardiotoxicity in rats: A biochemical, electrocardiographic and histopathological study. Indian J Pharmacol 2013;45:44-48.

13. Osama AA, Mohamed EE. Effect of lactoferrin on some selective immunological parameters in rats immunosuppressed by cyclophosphamide. J Investig Biochem 2013;2:136-140.

14. Shaha D, Londhe V, Mazumder R, Parikh R. Can levamisole alone maintain the immunity? International Journal of Pharmacy and Pharmaceutical Sciences 2011;3:161-164.

15. Feldman BF, Zinkl JG, Jain NC (Eds.). Text book of Shalm's Veterinary Hematology. $5^{\text {th }} \mathrm{Ed}$, Lippincott Wiliams \& Wilkins, Philadelphia 2000.

16. Coles EH (Ed.). In: Textbook of Veterinary Clinical Pathology. $4^{\text {th }}$ Ed, W.B. Saunders Company, Philadelphia 1986. 
17. Henry R J, Cannon D C and Winkelman J W (Eds.). Clinical chemistry, principles and techniques $2^{\text {nd }} \mathrm{Ed}$, Harper \& Row, Hagerstown, Maryland, USA 1974.

18. Doumas BT, Bayso DD, Carter RJ, Peters T, Schaffer R. Determination of serum albumin. Clin Chem Acta 1981;27:1642.

19. Parry RM, Chandan RC, Shahani KM. A rapid and sensitive assay of muramidase. Proc Soc Exp Biol Med 1965;119:384-386.

20. Siwicki AK, Anderson DP. Immunostimulation in fish: measuring the effects of stimulants by serological and immunological methods. US Fish Wildlife Service, IFI, Olsztyn1993;1:17.

21. Keller R, Keisi R, Wechsler A, et al. Mechanisms of macrophage-mediated tumor cell killing: A comparative analysis of the roles of reactive nitrogen intermediates and tumor necrosis factor. Int $\mathrm{J}$ Cancer 1990;466-482.

22. Angulo FGH, J F Garcia-Bustos JF, Gargallo D, Munoz-Fernandez MA, Fresno M. Nitric oxide-producing D11b+Ly-6G(Gr-1)+CD31(ER-MP12)+ cells in the spleen of cyclophosphamide-treated mice: implications for T-cell responses in immunosuppressed mice. Blood 2000;95:212-220.

23. Duncan D B. Multiple ranges and multiple F-test. Biometrics1995;11:1-42.

24. Brock N. Oxazaphosphorine cytostatics: past-presentfuture: seventh Cain Memorial Award lecture. Cancer Res 1989;49:1-7.

25. Winkelstein A. Mechanisms of immunosuppression: effects of cyclophosphamide on cellular immunity. Blood 1973;41:273-284.

26. Jolanta A, Michal Z, Marian LK. Enhanced clearance of Escherichia coli and Staphylococcus aureus in mice treated with cyclophosphamide and lactoferrin. Int Immunopharmacol 2004;4:1149-1157.

27. Swierczewska E, Niemiec J, Glowacka JN. A note on the effect of immunostimulation of laying hens on the lysozyme activity in egg white. Animal Sci Paper Reports 2003;21:63-68.

28. Khaksary M M, Ranjbar R, Arzi A, et al .Comparison study of effects of Echinacea extract and levamisole on phenytoininduced cleft palate in mice. Regul Toxicol Pharmacol 2006;46:163-166.

29. Holcombe R F , McLaren C E, Milovanovic T .Immunomodulation with low dose levamisole in patients with colonic polyps. Cancer Detect Prevent 2006;30:94-98.

30. Mohri M, Seifi HA, Zamani Sani SH. Effects of oral administration of levamisole on non-specific immunity, serum proteins and health in normal colostrumfed neonatal dairy calves. Compartive Clin Pathol 2005;13:132-136.

31. Saeed S E, Hadi k N, Narges A, et al. Synergetic effects of oral administration of levamisole and Echinacea purpurea on immune response in Wistar rat. Res Vet Sci 2011;91:82-85.

32. Senthilkumar S, Devaki T, Manohar BM, Babu MS. Effect of squalene on cyclophosphamide-induced toxicity. Clin Chim Acta 2006 ;364:335-342.

33. King PD, Perry M. Hepatoxicity of chemotherapy. Oncologist 2001;6:162-176.

34. Zhao R, Ma C, Tan L, Zhao X, Zhuang D. The effect of acupuncture on the function of macrophages in rats of immunodepression. Zhen Ci Yan Jiu 1994;19:66-68.

35. Hickmann-Davis JM, Lindsey JR, Matalon S. Cyclophosphamide decreases nitrotyrosine formation and inhibits nitric oxide production by alveolar macrophages in mycoplasmosis. Infect Immun 2001;69:6401-6410.

36. Choe Y, Lee S. Effect of lactoferrin on the production of tumor necrosis factor $\alpha$ and nitric oxide. J Cell Biochem 1999;76:30-36.

37. Crouch SPM, Slater KJ, Fletcher J. Regulation of cytokine release from mononuclear cells by the ironbinding protein lactoferrin. Blood 1992;80:235-240.

38. Shinoda I, Takase M, Fukuwatari Y, et al. Effects of lactoferrin and lactoferricin on the release of interleukin 8 from human polymorphonuclear leukocytes. Biosci Biotechnol Biochem 1996;60:521-523.

39. Sorimachi K, Akimmoto K, Hattori Y, leiri T, Niva A. Activation of macrophages by lactoferrin: Secretion of TNF-alpha, IL-8 and NO. Biotechnol Biochem 1997;60:521-523. 